\title{
Reflection of the Due Process Standards in Judgment in Absentia
}

\author{
Artur Malaj \\ Judge in the Administrative Appeal Court \\ Email: Artur.Malaj@yahoo.com
}

\section{Doi:10.5901/ajis.2015.v4n1p135}

\section{Abstract}

The right to a due process represents a vanguard mechanism for human rights and fundamental freedoms. This right, consisting of a set of fundamental principles that ensure the legality of the procedures or decision-making of state, serves as a guarantee of eliminating any arbitrariness in the exercise of state power over the individual. For this reason, it appears entirely important, especially for the person accused of committing a criminal offense, serving as a guarantee, as when he has chosen to speak out and defend in person before the court, or when he has decided to waive this right. This paper undertakes to handle the very second situation, taking in analysis the judgment in absentia, the cases in which it applies, and the rights that should be guaranteed the defendant in absentia within his right to a due process and their real effectiveness.

Keywords: judgment in absentia, due process, the defendant, standards, minimum rights

\section{Introduction}

The right to a due process is a fundamental right for the defendant who has committed a criminal act. This right, among the other guarantees, intends to provide to him the opportunity for a hearing and to defend himself in person, before the tribunal. However, a due process might be provided even in the absence of the defendant.

Judgment in absentia of a defendant is a consequence of the primary character of the public interest for the punishment of the crime, who expects an effective combat against criminality and who does not want the trials to be paralyzed. Hence, a balance has to be established between the right of the defendant for a due process and the interests of the justice.

Based on the importance of judgment in absentia institute to guarantee the public interest, but even according to the importance of every accused person's right for e due process, in this study, we are focusing on the reflection of the right for a due process provided for in article 6 of the European Convention on Human Rights (hereinafter ECHR), in judgment in absentia.

\section{Review}

The right to a due process represents a very early right that is perfected in parallel with the historical development of human society. Its first elements were reflected in the Great Charter of Freedoms (Magna Charta) of 1215, in which was predicted that: "No freeman shall be taken or imprisoned or disseized or exiled or in any way destroyed, nor will we go upon him nor will we send upon him except upon the lawful judgment of his peers or the law of the land."'. In this way, in this document is reflected for the first time in the legal route, the right to a legal trial.

This act was followed by many other acts, such as: Petition of Right, in 1628, the Habeas Corpus Act, in 1679 and the Bill of Right of 1689, which would continue with the sanctioning of the right to due process. So, for example the Petition of Right stated that : "No free man shall be deprived of liberty or his property without a legal process".

Meanwhile, if we refer to the common law, we understand that it has developed the concept of fair procedure in the doctrine of "natural rights". Under this approach, courts and other official bodies would act only after notification of affected parties and after they have had an opportunity to respond.

The right to due process, takes a broad sanction in the second half of the XIX-th century, being manifested in a number of legal acts of international character. Documents such as the Universal Declaration on Human Rights and the

${ }^{1}$ Article 39 of Magna Charta Libertatum. 
International Covenant on Civil and Political Rights, adopted by the General Assembly of the United Nations, respectively in 1948 and 1966, sanction so evolutionary the right to a due process, bringing a clear definition of the due process with all its constituent elements, mechanisms and guarantees for the effective exercise of this right.

However, it should be noted that the most important document in terms of reflecting and sanctioning of the right to a due process, remains the European Convention of Human Rights, which in its Article 6 details the elements of a fair trial, its rights and its minimum guarantees, noting that: "1.In the determination of his civil rights and obligations or of any criminal charge against him, everyone is entitled to a fair and public hearing within a reasonable time by an independent and impartial tribunal established by law. Judgment shall be pronounced publicly but the press and public may be excluded from all or part of the trial in the interest of morals, public order or national security in a democratic society, where the interests of juveniles or the protection of the private life of the parties so require, or the extent strictly necessary in the opinion of the court in special circumstances where publicity would prejudice the interests of justice.

2. Everyone charged with a criminal offence shall be presumed innocent until proved guilty according to law.

3. Everyone charged with a criminal offence has the following minimum rights:

(a) to be informed promptly, in a language which he understands and in detail, of the nature and cause of the accusation against him;

(b) to have adequate time and the facilities for the preparation of his defence;

(c) to defend himself in person or through legal assistance of his own choosing or, if he has not sufficient means to pay for legal assistance, to be given it free when the interests of justice so require;"

As seen, the right to a due process has been reflected in a number of international acts with legal character. However, in none of these acts, are treated the standards of this right in judgment in absentia. This task is best accomplished by the European Court of Human Rights. This way, in the case Sejdovic versus Italy, the Court decided the minimum standards that must be respected in the judgment in absentia, specifying:

a) The right to take part in the hearing and to obtain a new trial;

b) Waiver of the right to to appear at the trial;

c) Right of a person charged with a criminal offence to be informed of the accusations against him;

d) Representation by counsel of defendants tried in absentia

The analysis and the effectiveness of these rights will continue in the following issues.

\section{Research Methodology}

The idea for the realization of this scientific work, does originate from the identified problems in the judicial practice dealing with the judgment in absentia. Consequently, the research has begun highlighting the problems of the Albanian judiciary and confronting them with the jurisprudence of the ECHR regarding judgment in absentia and minimum standards that must be adhered to during it.

The methodology of this research consists of four phases:

- First phase: Selection of national and international legal literature that addresses the concept of a default judgment and selection of relevant jurisprudence of the ECHR and Albanian.

- Second Phase: Analysis and structuring the material selected and the jurisprudence.

- Third Phase: Personal contribution to this paper through the information and ideas discussed in conferences and trainings with lawyers and advocates, as well as publications in national magazines.

- Fourth Phase: Review of the paper and highlight the conclusions derived from it.

\section{Judgment in Absentia}

Basically, a due process requires the defendant's effective participation. However, if there are justifiable causes, the trial might be held even in the absence of the defendant ${ }^{2}$, provided that the minimal rights, provisioned by the $\mathrm{ECHR}^{3}$, are guaranteed to him. In this viewpoint, judgment in absentia shall not be considered in contradiction with article 6 of the ECHR.

\footnotetext{
${ }^{2}$ Nuala Mole and Catherina Harby, "The Right for a Due Process. A guideline on the implementation of article 6 of European Court on Human Rights", Strasbourg, Cedex, European Council, 2001, pg.38.

${ }^{3}$ Committee of the Ministers of the European Council has adopted the Resolution (75) 11 "On the criteria of the defendant's judgment in absentia", recommending the member states to take into consideration 9 minimal rules: 
Even the Albanian legislation has accepted the due process. So, article 33 in the Constitution provides that: "Everyone has the right for a hearing before he is judged. The person who absconds from justice cannot benefit from this right". In addition, the Criminal Procedure Code provisions explicitly the cases when it is possible to proceed with the judgment in the absence of the defendant 4 .

More concretely, pursuant to the Albanian legislation, judgment in absentia is permitted in four cases 5 :

The first case (the deliberate absence and the ascendance of the defendant) is related with the situation provided for in article 352(1) of the Criminal Procedure Code. In this case, the defendant, with his full awareness and will abdicates from his right to participate in the judgment, being represented by the attorney. According to paragraph 2 of article 252 of the Criminal Procedure Code, "The defendant who is present and then leaves the courtroom is considered to be present, provided that he is represented by the attorney".

The second case (the fugitive defendant) is connected with the case when the defendant absconds when it is proven that he is absconding form justice, according to the provisions of article 352 (4) of the Criminal Procedure Code. This case is provided for even by the Constitution in its $33^{\text {rd }}$ article.

The third case (the defendant fails to appear), is connected with the situation provided for in article 351 of the Criminal Procedure Code, which provisions the pronouncement of the absence when the defendant in free state or in detention fails to be present in the trial, even though he was duly notified. A due notice, pursuant to the due process, according to the constitutional guarantees provided for in article 31 of the Constitution and article 6(3) of ECHR, means the notification of the accused in person regarding the charge against him and the judicial process only when the notice is communicated to the accused in person. This standard is fulfilled only by point 1 of article 140 of the Criminal Procedure Code, in the part where it is provided that: "The defendant who is not in custody is notified when the copy of the act is handed to him (...)".

The fourth case (the defendant who cannot be found) is relevant with the somehow abnormal situation which is not connected with the defendant in free state, the absconder or the detained, but with the defendant who cannot be found, whose notification is regulated by the continuing part of article 140 and 141 of the Criminal Procedure Code, except for the case when the notice is received in person by the abovementioned accused. The difference of this case compared to the other cases mentioned above is essential. We cannot say that this defendant has abdicated unequivocally from his Constitutional rights provided for in articles 31-33 of the Constitution as well as in article 6 of ECHR or article 14 of the Pact. As in the three other cases it can be presumed that the defendants have had the opportunity to exercise their rights guaranteed by the Constitution and the other international acts including the right to choose an attorney, in the case of the defendant who cannot be found, this statement cannot be made here, as the defendant has not been given this opportunity yet, which means that he has not been notified about the trial against him.

According to the facts mentioned above, it can be found that if the Court intends to proceed with judgment in absentia, it has to prove, based on the actions of the defendant, that the latter has abdicated from the rights that stem from article 6 of the Convention and he has predicted the consequences of an action like this consciously ${ }^{6}$. Therefore, it is necessary to check if the defendant is duly notified regarding the proceeding that is being held against him 7 . However, despite the effective awareness, he decides to abdicate from the right to be present in the judgment.

\subsection{Notification of the defendant}

In the framework of organizing a due process, every person accused of committing a criminal act has the right to be

\footnotetext{
${ }^{4}$ Article 351 of the Criminal Procedure Code provides that: "1. When the defendant in free state or in detention fails to appear before the hearing even having been notified and there were no lawful excuses for the failure to appear the court, after hearing the parties, declares his absence. In this case he will be represented by the defense attorney." Article 352 of the Criminal Procedure Code provides that: "1. When the defendant requests or gives the consent that the court examination is performed in his absence or, as imprisoned, refuses to participate, he shall be represented by the defense lawyer. 2. The defendant who after appearing leaves voluntarily the hearing shall be deemed to be present, provided that he is represented by the defense lawyer. 3. The provisions of paragraph 2 shall also apply when the detained defendant leaves at any time of the court examination or during its intervals. 4. The trial in absentia may be also held when proven that the defendant is absconding."

${ }^{5}$ For more information, refer to the Unifying Decision no.1, dated March 2014 of the Joint Colleges of Supreme Court, pg. 32-35.

${ }^{6}$ Check Jones against the United Kingdom, application no.30900/02, dated 9 September 2003

${ }^{7}$ We refer to case 2, 3 and 4 mentioned above, because in the first case, the announcement of the defendant is presumed to be effective, because he leaves the courtroom with his full will after he appeared there at the beginning.
} 
noticed with regard to the charges against him 8 . The process of informing this person about an open trial against him is a judicial act of a special importance, which has to be carried out in compliance with the procedural and essential requirements, which guarantee the effective enforcement of the rights by the defendant ${ }^{9}$.

Even the European Court of Human Rights highlights the fact that the notification of the prosecution plays an important role in the progress of the proceeding, because from that moment the defendant is informed officially about the charges against him and the legal basis where they are based on ${ }^{10}$. Hereby, he is guaranteed the opportunity to duly exercise his rights ${ }^{11}$. Consequently, the notice, carried out in compliance with the conditions provided for in law, is fundamental.

Based on the importance of the notification of the defendant, in the Criminal Procedure Code, there is a specific unit about the rules of the notification in general and for the defendant in particular. Therefore, article 139 of the Criminal Procedure Code provisions the rules for the notification of the defendant in free state. Article 141 provisions the rules for the notification of the defendant who cannot be found even though sufficient investigation has been made. Finally, article 142 of the Criminal Procedure Code provisions the notification of the defendant who is abroad.

It results that the Criminal Procedure Code provisions the notification rules for the defendant according to his concrete situation. However, the criteria which must be respected according to the formal viewpoint, for an effectual notice, are not explained effectively in the code. Therefore, we have to refer to the a contrario interpretation of article 143 of the Criminal Procedure Code, because the latter provisions the cases of the notice invalidity. Consequently, it is found that:

1. The act should be notified completely.

2. The signature of the body which has prepared the notice must not miss in the copy of the notified act.

3. The special provisions on the person, the copy must be handed to, must be respected.

4. The notice for the defendant in free state must be displayed.

5. In the case of the notification pursuant to article 140/1 of the Criminal Procedure Code, the signature of the person who is responsible for the notification must be found in the original version of the notification act.

6. In the case of the notification via special technical means, the forms for the notification in this way must be respected rigorously.

The obedience to these rules is a duty of the competent authorities, so that in formal terms, the notification can be considered duly made.

However, even though the notification might be considered duly made in formal terms, it is not sufficient to guarantee that the defendant was notified effectively about the judgment against him. Consequently, the court must not be satisfied only with the verification of the formal aspect of the notification to presume that he is absconding from justice. It has to make the necessary verifications to make sure that the defendant was notified effectively ${ }^{12}$.

Even the European Court of Human Rights argues that just one formal notification cannot give way to the irreversible legal presumption that the defendant is aware of the proceedings. Anyway, according to the European Court of Human Rights, even the opposite presumption would still be unjustifiable, because it would deny the fact that the defendant is aware of the proceedings as long as there is evidence that proves that he is guilty and is hiding away ${ }^{13}$.

Therefore, despite being necessary, the existence of a notification system with a formal character should not aggravate the defendant's position and to result in presumptions which are not favourable for the latter. That is why the burden of the proof that the defendant was notified effectively regarding the judgment against him belongs to the state. Only in this way are the defendant's rights and the obligations of the state (which must not remain only in the formal level) balanced.

\footnotetext{
${ }^{8}$ Article 6, pg. 3/a of ECHR

9 Decision no. 30, dated 17 June 2010 of the Constitutional Court, pg. 29

10 Sejdovic against Italy, application no. 56581/00, dated 1 March 2006, pg.89. See even Kamasinski against Austria, application no. 9783/82, dated 19 December 1989, pg.79.

11 Sejdovic against Italy, application no. 56581/00, dated 1 March 2006, pg.8.9 See even Somogyi against Italy, application no. 67972/01, dated 10 November 2004, pg. 75.

12 We emphasize that the obligation to notify the defendant does not belong only to the First Instance Court but even to the Appeal and the Supreme Court. This obligation exists even in those cases when the defendant has chosen with his free will to be represented by a defense attorney, or the latter is ascertained by the proceeding body. This obligation focuses on taking the measures to carry out the notification in compliance with the formal criteria defined above.

${ }^{13}$ Sejdoviç against Italy, application no. 56581/00, dated 1 March 2006, pg. 65.
} 
In conclusion, we would like to emphasize that it is the duty of the respective state authorities, to notify the defendant, against whom a criminal process has commenced, rigorously, in compliance with the procedural requirements, because this is the only way to find out that the defendant has abdicated, with his free will, from the participation in the judgment and has accepted to be judged in absentia ${ }^{14}$. It is the duty of the competent organs to check these facts ${ }^{15}$.

\subsection{Abdication from the exercise of the right ${ }^{16}$}

As it was mentioned even above, judgment in absentia requires, that despite the effective notification of the defendant about the proceeding against him, at the end the latter's decision not to participate in it prevails. The proceeding authorities must be sure and must not presume that the defendant is a person who is absconding from justice concluding that he has abdicated voluntarily from the right to participate in judgment ${ }^{17}$. This means that it should not be presumed that the defendant has been informed only because of the notifications that were found in the investigation file and in the judgment file. However, the court has to judge the evidence to conclude if he was aware or not of the proceedings against him.

Based on the reasoning above, judgment in absentia should be permitted if the file includes documents which prove that the defendant has abdicated voluntarily form the right to be present in the judgment or that he is absconding from justice; as long as the competent authorities prove that he was effectively informed about the process ${ }^{18}$.

In conclusion, we would like to emphasize the fact that it is essential that the defendant is offered the rights and the procedural guarantees effectively and if the abdication from the exercise of these rights is proven, judgment in absentia may be applied ${ }^{19}$.

\subsection{Right of Defense}

Every accused person's right to defend himself effectively via a defense attorney represents one of the most essential rights in the framework of the due process provided for in article 6 of the ECHR and article 42 of the Constitution. It is one of the main indicators of a fair judgment ${ }^{20}$. Consequently, an accused person cannot miss the benefit of this right just because he is not present in the judgment ${ }^{21}$.

In the Albanian legislation, this right is reflected in the part of the fundamental principles of the Criminal Procedure Code, which defines how the criminal proceeding has to be carried out 22 . It is mirrored even in the case of judgment in absentia23.

14 In the law-case Colozza against Italy, the European Court of Human Rights stated that: "The decision of the court to proceed with judgment in absentia, has to be made, only if after the appropriate assessment regarding the efficiency of the notification of the defendant, the latter is found to have avoided voluntarily the execution of an arrest warrant or any other security measure". See Colozza against Italy, application no. 9024/80, dated 12 February 1985, pg. 28.

${ }^{15}$ Decision no. 30, dated 17 June 2010 of the Constitutional Court, pg. 34.

${ }^{16}$ If we refer to article 352 of the Criminal Procedure Code, the ascertainment of the abdication from the right to be present in the process does not have any difficulties if the defendant was present once and then gives his consent for judgment in absentia or he leaves the courtroom, proving his will concretely. The difficulty refers to the cases when it is assumed that the defendant is absconding from justice, because the authorities have to prove this fact (article 352/4).

${ }_{17}$ Colozza against Italy, application no. 9024/80, dated 12 February 1985, pg. 34.

18 In the law case Sejdovic against Italy, the European Court of Human Rights emphasized that: "If an accused person is not notified in person just because of his status as an "absconder", which was based on an unfounded presumption, he is not considered to have abdicated from his right to be present and to defend his own self in the judgment. Before a defendant is considered to have abdicated from this right, it has to be proven that he has predicted its consequences reasonably. Furthermore, the defendant must not face the burden of the evidence that he was trying to abscond from justice". Sejdovic against Italy, application no. 56581/00, dated 1 March 2006, pg. 87-88. Also See Colozza against Italy, application no. 9024/80, dated 12 February 1985, pg. 28.

19 Potrimonol against France, application no. 277-A, 23 November 1993, pg. 31.

$20 \mathrm{lbid}, \mathrm{pg} .14$ and 34.

${ }^{21}$ See Mariani against France, application no. 43640/98, dated 31 March 2005, pg. 31 and 40.

${ }^{22}$ Article 6 of the Criminal Procedure Code provides that: "1. A defendant is entitled to self-defense or to defense by a defense lawyer. In case of insufficient means, he shall be provided legal aid. 2. A defense lawyer shall assist the defendant to have all procedural rights guaranteed and his legitimate interests protected."

${ }^{23}$ See article 351 and 352 of the Cr.Pr.C. 
It is important to highlight the fact that in a judgment in absentia, the appointment of a defense attorney ${ }^{24}$, mainly by the court, is an obligation for this institution, in the framework of carrying out a due process. Anyway, this obligation rises only if the defendant in absentia has not chosen a defense attorney himself or via his familiars, who represent his free will ${ }^{25}$.

In each of the cases, the effective right of protection is important in order to guarantee the procedural rights and the legal interests of the defendant. Let us stop at the analysis of the efficiency of the defense in each case.

\subsubsection{The appointed defense attorney}

As we emphasized it even in the case of judgment in absentia, the appointment of a defense attorney from the proceeding body represents an obligation for it. However, this obligation does not guarantee at the same time even the efficiency of the defense which is carried out mainly by the appointed lawyer. So, the appointment of an attorney represents a necessary condition which is not sufficient to provide an effective defense.

Theoretically, the appointed defense attorney is mainly obliged to carry out the defense in an honest way respecting the rules of the professional ethics and avoiding the conflicts of the interests. He has to use all the legal means to defend the rights and the interests which are defended or represented by him ${ }^{26}$.

Regardless of what was mentioned above, the appointed defense attorney does not always carry out an effective defense, conform his legal obligations. Furthermore, the Criminal Procedure Code does not provision the right and the obligation of the proceeding body to take a measure provided that the appointed defense attorney breaches the required standards to fulfill an effective defense. The only opportunity in this case for the proceeding body is to refer to the Board of Directors of the National Bar Association the cases of withdrawing from the defense, of the refusal of the defense and the violences of the duties of loyalty and honesty by the defense attorneys ${ }^{27}$. However, only the latter has the right to take disciplinary measures in this situation ${ }^{28}$.

It is found that the competent bodies might intervene in the way how the appointed defense is carried out, mainly in some classical cases (for example the cases of repeated absences). Also, other mechanisms, such as taking disciplinary measures, are missing. Under these circumstances, the defense of the appointed attorney is not considered to have accomplished the efficiency criteria.

Furthermore, the defense via a representative is the result of a special relation between them based on the confidence report helping the defendant to instruct the defense attorney or if he does not comply with his instructions, he can substitute him ${ }^{29}$. Meanwhile, in the case of the appointed defense attorney, because of judgment in absentia, exactly for this reason, this relation cannot be established and the defendant cannot exercise his rights. Therefore, the efficiency of the defense is not very reliable.

However, we should accept the fact that the authorities cannot be responsible for every flaw regarding the way how the legal assistance is offered by the appointed defense attorney. Pursuant to article $6 / 3$ of the European Convention on Human Rights, they are compelled to intervene only if the appointed defense attorney fails to give the legal assistance prominently30.

In conclusion, we would like to emphasize the fact that the active presence of the defense attorney is essential to guarantee the defendant's rights who is judged in absentia, balancing the judgment in absentia and respecting the right of the right provided for in article 6 of the Convention ${ }^{31}$. However, its efficiency might be violated provided that there are no sanctions against the defense attorney, for not duly performing his duties.

\subsubsection{The defense attorney chosen by the familiars}

\footnotetext{
24 The attorney's appointment must not be confounded with the choice of the defense attorney because the "choice" implies a defendant's right which he can exercise or not, based on the assessment for the defense of his own rights. Meanwhile, the appointment of the defense represents an obligation for the court in the cases provided for in law.

${ }^{25}$ See article 48 of the Cr.Pr.C. as well as the Unifying Decision no. 1 dated 10 March 2014 of the Joint Colleges of the Supreme Court.

${ }^{26}$ Law no. 9109, dated 17.7.2003 "On the Profession of the People's Advocate in the Republic of Albania", article 9, point 1 and 2.

${ }_{27}$ See article 56/1 of the Cr.Pr.C.

${ }^{28}$ See article $56 / 2$ of the Cr.Pr.C.

${ }^{29}$ See article 50/3 of the Cr.Pr.C.

30 Sejdoviç against Italy, application no. 56581/00, dated 1 March 2006, pg. 36.

31 lbid, pg. 69.
} 
The Criminal Procedure Code provisions even the opportunity that the defendant's familiars choose the defense attorney. More concretely, article 48/3 of the Criminal Procedure Code provides that: "The appointment of a defense attorney for the person in custody, for the person arrested or for the one imprisoned, as long as this person has not made the choice himself, might be made by one of his relatives in compliance with the forms provided for in paragraph 2". As it can be noticed, the article itself restricts the defendant's relatives' right to choose the defense attorney of the defendant 32 .

In the interpretation of these restrictions, the Supreme Court, in its Unifying Decision, no.1, dated 10 March 2014 concludes that the appointment of the defense attorney by the defendant's familiars, according to the meaning of article 48(3) of the Cr.Pr.C., might occur when the defendant is in the condition of his personal freedom restriction, therefore in the availability of the justice authorities and is sufficiently aware of the existence of a criminal proceeding against him. If the defendant is not physically detained and if there is not sufficient evidence to believe that he is aware of the criminal proceeding against him, then the appointment of the defense attorney by the relatives of the defendant judged in absentia shall be considered, due to the procedural law, as an appointed defense attorney. So, the defense attorney chosen by the familiars shall be accepted by the tribunal legitimating him and acknowledging his right as an appointed defense attorney, which are the procedural rights the latter has got during the criminal process except for the rights which are recognized by the law as the defendant's exclusively personal rights. However, if the defendant absconds and asks to exercise his right of defense delegating the right to choose a defense attorney to one of his relatives (or to a friend), if it is proven that this is the result of his full and unequivocal will as the holder of this right (i.e. the defendant) ${ }^{33}$, pursuant to the procedural aspect, the court has to consider this action in compliance with article 48(1) (selection of the defense attorney by the defendant in person), as well as pursuant to article $410(1)$ of the Cr.Pr.C.

Therefore, in the case of a judgment in absentia, when the defendant is not present physically and when there is not sufficient evidence to believe that he is aware of the criminal process against him, the defense attorney selected by the familiars, for the effect of the procedural law will be equaled with the appointed defense attorney. Meanwhile, if the delegation of the right to choose a defense attorney is delegated to the relatives, who express the defendant's full will, then, the defense attorney shall be considered as chosen by the defendant himself.

Even though the selection of the defense attorney in each of the abovementioned situations intends to protect the rights of the defendant in absentia, its efficiency cannot be guaranteed. The lack of the efficiency stems from the fact that there is a lack of the special relation based on the report of trust which is settled directly between the defendant and his defense attorney.

Therefore, when the defendant is not present physically and there is not sufficient evidence that he is aware of the proceeding that is being held against him, the absence of the relation between him and his defendant is evident. Provided that the delegation of the right to select the defense attorney to the relatives is proven, even though in principle it is presumed that the familiars always indent to protect the defendant's rights, still it is not sufficient to guarantee its efficiency. This happens due to the unreliability on the relation between the defendant in absentia and his defense attorney, in the sense that the defendant himself instructs his defense attorney or that he can exercise his right to substitute him, if he finds out that the defense attorney is not acting in compliance with his instructions.

\footnotetext{
32 In the Unifying Decision no. 1, dated 10th March 2014, the Joint Colleges of the Supreme Court held that: "According to the draft of this provision, it is found that the relative is restricted to find a defense attorney, in two directions: ratione personae and ratione temporis. Based on the ratione personae aspect, the relative is permitted to choose a defense attorney for (1) the person in custody, (2) the person under arrest or (3) the imprisoned person. Regarding the two first options, it is easily understood that the person is found in the physical conditions of personal freedom restriction. Regarding the third option, provided for in article 48(3) of the Cr.Pr.C. - regarding the imprisoned person - pursuant to the provision in our procedural criminal legislation of the institute of judgment in absentia33, two different factual situations might turn up. The imprisoned person might be in the conditions of suffering the imprisonment in an institution of the criminal decisions execution. In a case like this, his status in vinculis matches with the situation of the person in custody of the arrested person. The common element in these three cases is the situation of the person under the conditions of his personal freedom restriction... another situation might turn up in the case of judgments in absentia. It might be possible that the judgment with imprisonment might have been made in absentia and its execution might have not been carried out yet... In the aspect ratione temporis, the relative is permitted to choose a defense attorney "as long as this person [the holder of the right] has not made the choice himself". Therefore, the provision implies that the relative's choice has to be limited in time and it has to be temporary." See pg.19-21 of the Decision.

${ }^{33}$ This is even the opinion of the Constitutional Court in the decision no. 30, dated 17 June 2010 (pg. 45-46), where it holds that the defendant's familiars might submit a complaint only if they are accomplishing the defendant's will and only if the defendant is aware of the criminal process that is being held against him and that the court has to accept the defense attorney chosen by the defendant's familiars; only if it finds that they are acting in compliance with the order that they have received from the defendant.
} 


\subsection{Notification of the decision}

If the abovementioned guarantees are respected rigorously, which means: the defendant is notified effectively about the proceeding against him and it is proven that he has abdicated from the right to be present, consequently it is decided to proceed with judgment in absentia and the defendant in absentia is appointed a defense attorney or the latter is selected by him or his familiars, the proceeding is valid. The decision made at the end of the judgment, has to be notified to the defendant judged in absentia. Based on article 3862/2 of the Cr.Pr.C., the notice about the filing of the decision in the secretary and its copy, are notified to the defendant in absentia, complying with the provisioned rules on the notifications, according to articles 140 and 141 of the Cr.Pr.C.

The communication of the decision as mentioned above gets an essential importance, as it guarantees to the defendant judged in absentia another fundamental right, the one to appeal against the decision of the court against him, or to reopen the proceedings carried out in absentia if it is found out that the judgment was held in absentia, which is not his fault.

\section{The Right to Reopen the Proceedings Carried out in Absentia}

A judgment in absentia presumes that the defendant has abdicated from his right to be present in the judgment, despite having effective information about it. However, it might happen that the defendant is judged in absentia and this is not his fault. In a case like this, he has to be given the right to reopen the procedures carried out in absentia ${ }^{34}$, in order to guarantee to him the right to be heard and to defend himself in person before the court, as well as the right to appeal.

The jurisprudence of the European Court of Human Rights emphasizes the fact that a rejudgment or a reopening of the case, if it is required by the applicant, basically represents the due way to settle the violence. This is in compliance with the instructions of the Committee of the Ministers, which more concretely in Recommendation no. R (2000)2 requires to the Member Countries of the Convention the implementation of the mechanisms to reexamine the case and to reopen the judicial procedures at the domestic level 35 . The existence of the legal means to satisfy the violence in this situation has to be very certain, not only theoretically but even practically, because their absence causes even the absence of the necessary access and efficiency ${ }^{36}$.

Consequently, it is found out that pursuant to the right for a due process, the domestic legislation has to provide effective means to reopen the judicial proceeding carried out in the absence of the defendant, but not due to his fault. Their determination belongs to the assessment of the state as long as they are clear and effective, in theory and in practice as well.

If we refer to the Albanian legislation, the Criminal Procedure Code provides the right to reinstate the time-limit for the defendant who was judged in absentia, which is not his fault ${ }^{37}$. However, referring to the unifying decision no.1, dated 20 January 2011, of the Joint Colleges of the Supreme Court, the right for the reinstatement of the time-limit might be exercised only if:

1. the defendant has not consumed the right of appeal via his defense attorney ${ }^{38}$, only if the review in the Appeal

\footnotetext{
34 This is an essential right to guarantee the right to have access as one of the fundamental rights guaranteed by the ECHR, which despite not being provisioned expressively in article 6 of the ECHR, it stems from its content.

35 Shkalla against Albania, application no. 26866/05, dated 10 May 2011, pg 78

${ }^{36}$ Aksoy against Turkey, application no. 21987/93, dated 18 December 1996, pg.5

${ }^{37}$ Article 147, Reinstatement of the time-limit: "1.The prosecutor, the defendant, private parties and defence lawyers shall be reinstated the fixed time-limit when they prove to have not been able to observe the time-limit due to mischance or force majeure. 2. In case the decision is rendered in absence the defendant may request the reinstatement of the time-limit to make an appeal when proves that he has not been notified of the decision. 3. The request to reinstate the time-limit is presented within ten days from the disappearing of the fact which constituted mischance or force majeure, whereas in cases provided by paragraph 2 from the day when the defendant has become effectively aware of the act. The reinstatement of the time-limit is not permitted more than once for each party for each stage of the proceedings. 4 . The request is subject to the decision of the authority which proceeds at the time of its presentation. 5 . The decision permitting the reinstatement of the time-limit for making the appeal is appealable only along with the final decision. 6. The decision refusing the request for reinstatement of the time limit is subject to an appeal to the Court of Cassation."

${ }^{38}$ Regarding the defendant's right to complain, in the Unifying Decision no. 1, dated 10 March 2014, the Joint Colleges of the Supreme Court hear that: "The defendant is permitted to personally delegate the right to appeal at the defense attorney. The delegation act might be in the same act the selection of the defense attorney is made with, or in another separate act... The defendant is also permitted to delegate the right to appeal at the defense attorney exercising this will via the delegation to a relative. The relative does not choose a
} 
Court or in the Supreme Court has been made only based on the prosecutor's appeal ${ }^{39}$.

2. in the case of a common judgment for several defendants, the highest court has decided not to accept the appeal of one of the codefendants for one of the cases provisioned in article 420, point 1 of the Cr.Pr.C.

3. in the case of a common judgment for several defendants, no one has appealed or if the appeal of one of the codefendants is based on personal motives.

Meanwhile the defendant judged in absentia cannot exercise his right for reinstatement of the time-limit, because it contradicts the principle ne bis in idem ${ }^{40}$. Under these circumstances, the right for reinstatement of the time-limit represents an inefficient procedural means for the reopening of the proceedings held in absentia of the defendant, as its exercise in practice is violated.

On the other hand, according to the standards of a due process the defendant judged in absentia must have the right to reopen the proceedings carried out in his absence ${ }^{41}$, if it is found out that he was not aware of them or because he found it objectively impossible to participate. In a situation like this, two viewpoints are noticed in the Albanian jurisprudence regarding the procedural means of the defendant to reopen the proceedings carried out in his absence: the request for review and the appeal in the Constitutional Court.

According to the jurisprudence of the ECHR, the procedural means for the reopening of the proceedings carried out in absentia, two main criteria shall be fulfilled: to be clear and effective in theory as well as in practice. Consequently it is necessary to analyze if the abovementioned means fulfill the conditions to be considered as effective to guarantee the defendant's procedural right to reopen the proceedings carried out in absentia but not because it was his fault.

\subsection{Request for review}

The review of the decisions is an extraordinary means of appeal against the final decisions. It implies the review of the concluded judicial cases with a final decision in order to modify or abrogate it ${ }^{42}$. The request for review is based on the causes which are provisioned in article 450 of the Cr.Pr.C. More concretely, the review of the decision might be required when:

a) the facts on the bases of the decision do not compel with the ones of another final decision;

b) the decision is based on a decision of the civil court, which is later on revoked;

c) after the decision, new evidence is found or discovered, which alone or along with the ones which was once assessed indicates that the decision is wrong;

d) it is proven that the decision is a consequence of a fraud of the judgment acts or of another fact provided for by the law as a criminal act.

As it can be noticed, the review of the judgment in absentia (which is not the fault of the defendant) is not provided. Under these circumstances, even though in practice the opportunity for a review of the criminal decision because of the judgment in absentia (which is not the defendant's fault) might be accepted, these procedural means cannot be considered effective, as long as there aren't any legal provisions but just one interpretation of the judicial jurisprudence. This conclusion comes from the fact that the criteria determined by the jurisprudence of the ECHRs specify that the procedural means for the reopening of the procedures in absentia firstly has to be provided for by law, i.e. it has to be effective in theory and not just in practice.

defense attorney and does not delegate the right to appeal autonomously. The appeal of the defense attorney selected by the relatives is permitted only if it is proven that (i) the selection of the defense attorney and (ii) the delegation of the defense attorney to exercise this appeal is the result of the full and unequivocal will of the holder of this right, that means the defendant". See pg.54 of the Decision.

${ }^{39}$ Article $147 / 3$ of the Cr.Pr.C.: "'"

40 See the Unifying Decision no. 1, dated 20 January 2011 of the Joint Colleges of the Supreme Court.

${ }^{41}$ In the case Colozza against Italy, ECHR held that: "When the national laws permit the judgment in absentia for a criminally accused person, as soon as he is informed about this proceeding, he shall have the right for a hearing in the court on the claims of the prosecution." Colozza against Italy, application no. 9024/80, dated 12 February 1985. Pg. 29. Meanwhile, in the case Krombach against France, the court held that: "The person convicted in absentia shall be guaranteed the right of appeal, at least once against the judicial decision to present his objections against the procedural breaches, to guarantee to him a contradictory judgment and to guarantee to him the exercise of the defense42". Krombach against France, application no. 29731/96, dated 13 February 2001, pg. 99.

42 Halim Islami, Artan Hoxha and Ilir Panda, "Criminal Procedure", Morava Publication, Tirana 2007, pg. 667. 


\subsection{Appeal in the Constitutional Court}

Pursuant to article $131 / f$ of the Constitution ${ }^{43}$, the individual has the right to lodge an appeal in the Constitutional Court only in connection with his right for a due process, after he has consumed all the other means permitted by the Albanian Constitution and law. More concretely, the individual can make a request only after his case is examined by the three instances of the court, because it is presumed that for all his constitutional rights, he may ask defense from the common courts, which have to provide a due process ${ }^{44}$.

In case of judgment in absentia (which is not his fault) in the three instances of the judgment, we may conclude that he was negated the right for a hearing and to defend in person in the court. Therefore, his right for a due process has been violated. This conclusion is based on the fact that the judgment in absentia is preceded by the exhaustion of all the opportunities to notify the defendant for the proceeding against him. If the first instance court, violating the rules for the notification of the defendant, has proceeded with the judgment in absentia, it is the responsibility of the appeal court to satisfy the violations, examining the appeal in general pursuant to article 425 of the Cr.Pr.C. The same reasoning is valid even for the Supreme Court. Therefore, the highest court has not been prudent to satisfy the permitted violations and deficiencies, which are found out in the judgment in absentia, after the codefendant judged in absentia is notified about the decision, the only opportunity for him remains "The Appeal in the Constitutional Court" for a violation of the due process ${ }^{45}$. Under these conditions he has the right and is legitimated to lodge an appeal in the Constitutional Court.

Therefore, "The Appeal in the Constitutional Court" for the violation of the right for a due process, as it is provisioned expressively in the Constitution, represents an effective means in the theoretical meaning. On the other hand, even in practice, it has been exercised effectively ${ }^{46}$. Consequently, it fulfills the required criteria based on the jurisprudence of the ECHR to be considered as an effective means to reopen the procedures in the absence of the defendant, which is not his fault ${ }^{47}$.

\section{Concluding Remarks}

$>$ Judgment in absentia shall not considered in contradiction with the right for a due process if the defendant judged in absentia is guaranteed the minimal rights provisioned by the European Convention on Human Rights.

$>$ Before the Court decides to proceed with the judgment in absentia, based on the actions of the defendant, it has to check out if the latter has abdicated from the right to be present and to defend himself in person before the court and that he has predicted the consequences of this action consciously.

$>$ In the framework of a due process, every person accused for committing a criminal offence has the right to be notified about the charges against him. His notification represents a judicial act of a special importance, which has to be carried out in compliance with the essential procedural requirements, which guarantee the effective exercise of the defendant's rights.

$>$ The court must not be satisfied only with the control of the formal aspect of the notification and then to presume that he is absconding from justice. It has to carry out all the necessary controls to make sure that the defendant has been notified effectively.

$>$ Based on the fact that the existence of a notification system with a formal character does not guarantee the effective notification of the defendant about the proceeding that is being carried out against him, in order to avoid the aggravation of his position due to the unfavourable presumptions about him, the burden to prove the effective notification of the defendant about the judgment against him, must be deputed to the state.

$>$ The defendants judged in absentia have to be offered the procedural rights and the guarantees effectively, so that the judgment in absentia can be carried out if it proven that the abdication from these rights does not give

\footnotetext{
${ }^{43}$ Article 131 of the Constitution: "'"

${ }^{44}$ Luan Omari and Aurela Anastasi, "Constitutional Law", ABC Publications, Tirana 2010, pg. 463-464.

45 Decision no. 5, dated 25 February 2013 of the Constitutional Court

${ }^{46}$ See for example Decision no. 118, dated 30 October 2012 of the College of the Constitutional Court, Decision no. 5, dated 25 February 2013 of the Constitutional Court, etc.

${ }^{47}$ The Appeal in the Constitutional Court is considered as an effective means to guarantee the defendant's right to reopen the judicial process in absentia even by the jurisprudence of the ECHR. It holds that: "'. See Shkalla against Albania, application no. 26866/05, dated 10 May 2011, pg. 59-62.
} 
way to suspicions.

$>$ The defendant judged in absentia must be guaranteed the right to be defended by a defense attorney who is appointed by the court, if he is not chosen by the defendant or his relatives.

$>$ The right for defense is essential to guarantee the rights of the defendant who is judged in absentia, establishing a balance between judgment in absentia and the right provided for in article 6 of the Convention. However, both the defense by the appointed defense attorney as well as the defense by the defense attorney chosen by the familiars represent a necessary but insufficient condition to guarantee an effective defense.

$>$ At the end of the judgment, the defendant judged in absentia has to be communicated the decision. In this way, he is guaranteed the right to appeal against the decision against him or to reopen the proceedings carried out in absentia, which was not his fault.

$>$ The jurisprudence of the ECHR holds that a rejudgment or reopening of the case, as long as it is required by the defendant judged in absentia, which was not his fault, basically represents the right way to justify the violation.

$>$ The existence of the legal means to satisfy the violations in this situation has to be clear and certain, not only in theory but even in practice because their absence causes even the absence of the access and necessary efficiency. Therefore, the procedural means to reopen the procedures carried out in absentia has to accomplish two criteria: to be effective, in theory (the provision of the law) and in practice as well.

$>$ The Cr.Pr.C. provides the right for the reinstatement in the time-limit about the defendant's judgment in absentia, which is not his fault. However, pursuant to the unifying decision $1 / 2011$, this right cannot be exercised in all the cases; for example: if in the case of the common judgment for some codefendants the right to appeal is exhausted, not for personal reasons, the codefendant judged in absentia cannot exercise the right of reinstatement of in a period of time, because it contradicts the principle ne bis in idem, and consequently it represents an ineffective procedural means.

$>$ Pursuant to this situation, two viewpoints are noticed in the Albanian jurisprudence regarding the procedural means of the defendant to reopen the proceedings carried out in absentia: the request for review and the appeal in the Constitutional Court.

$>$ The review of the decisions cannot be considered as an effective means to reopen the procedures in absentia. This conclusion comes from the fact that even though it has been applied in practice, hence its efficiency is guaranteed in a practical viewpoint, in the Cr.Pr.C. the case of the judgment in absentia, which is not the defendant's fault, is not provided as a reason for review, thus it violates its efficiency theoretically. Consequently, the required criteria of the ECHR jurisprudence, which requires the guarantee of efficiency in theory as well as in practice, are not fulfilled.

> The complaint in the Constitutional Court for violation of the right for a due process, as it is provisioned expressively in the Constitution, represents an effective means in the theoretical meaning. On the other hand, it is being applied effectively even in practice, so, it fulfills the required criteria based on the jurisprudence of the ECHR to be considered an effective means to reopen the procedures in absentia, which is not his fault.

\section{References}

European Convention on Human Rights.

Constitution of the Republic of Albania.

Resolution (75) 11 of the Committee of the Ministers of the Council of Europe.

Criminal Procedure Code of the Republic of Albania.

Law no. 9109, dated 17.7.2003 "On the Profession of the Advocate in the Republic of Albania"

Magna Charta Libertatum

Nuala Mole and Catharina Harby, "The right for a fair process. A guideline on the implementation of article 6 of the European Convention on Hyman Rights" Strasbourg, Cedex, Council of Europe, 2001.

Halim Islami, Artan Hoxha dhe Ilir Panda, "Criminal Procedure", Morava Publications, Tirana 2007.

Luan Omari and Aurela Anastasi, "Constitutional Law", ABC Publications, Tirana 2010.

Jones against the United Kingdom, application no. 30900/02, dated 9 September 2003.

Kamasinski against Austrisa, application no.9783/82, 19 December 1989.

Sejdovic against Italy, application no. 56581/00, dated 1 March 2006.

Somogyi against Italy, application no. 67972/01, dated 10 November 2004.

Colozza v Italy, application no. 9024/80, dated 12 February 1985.

Mariani against France, application no. 43640/98, dated 31 March 2005. 
Potrimonol against France, application no. 277-A, 23 November 1993.

Shkalla against Albania, application no.26866/05, dated 10 May 2011.

Aksoy against Turkey, application no. 21987/93, dated 18 December 1996.

Decision no. 30 dated 17 June 2010 of the Constitutional Court

Decision no. 118, dated 30 October 2012 of the College of the Constitutional Court

Decision no. 5 , dated 25 February of the Constitutional Court.

Unifying Decision no. 1, dated 20 January 2011, of the Joint Colleges of the Supreme Court Unifying Decision no. 1, dated 10 March 2014, of the Joint Colleges of the Supreme Court. 